\section{J U R N A L M E T M O R F O A \\ Journal of Biological Sciences \\ ISSN: 2302-5697 \\ http://ojs.unud.ac.id/index.php/metamorfosa}

\title{
PERSILANGAN INTERSPESIFIK ANGGREK HITAM (Coelogyne pandurata) DENGAN ANGGREK MUTIARA (Coelogyne asperata)
}

\section{INTERSPESIFIC HYBRIDISATION OF BLACK ORCHID (Coelogyne pandurata) AND PEARL ORCHID (Coelogyne asperata)}

\author{
Ni Wayan Deswiniyanti ${ }^{1 *}$, Ni Kadek Dwipayani Lestari ${ }^{2}$ \\ ${ }^{1}$ Fakultas Ilmu Kesehatan Sains dan Teknologi, ${ }^{2}$ Prodi Biologi, Fakultas Ilmu Kesehatan Sains dan Teknologi, \\ Universitas Dhyana Pura, Badung, Bali, 80361 \\ *Email: deswinfortuna@gmail.com
}

\section{INTISARI}

Anggrek hitam (Coelogyne pandurata) dan anggrek mutiara (Coelogyne asperata) adalah anggrek dari habitat asli hutan Kalimantan yang memiliki bentuk dan warna yang menarik sebagai tanaman hias dan mulai banyak dicari dan dijual kepada masyarakat namun upaya budidaya masih sangat terbatas. Salah satu upaya yang dilakukan untuk mencegah jumlah populasi anggrek hitam dan anggrek mutiara semakin menurun adalah melalui metode persilangan interspesifik untuk mempertahankan atau menghasilkan jenis maupun varietas baru tanaman anggrek. Salah satu informasi yang diperlukan dalam pemuliaan tanaman adalah kompatibilitas. Kompatibilitas persilangan Coelogyne pandurata $x$ Coelogyne asperata belum diketahui. Penelitian ini bertujuan untuk mendapatkan waktu yang tepat untuk melakukan persilangan. Pada penelitian ini penyerbukan dilakukan pada hari ke 2 dan hari ke 5 setelah bunga mekar. Penyerbukan dilakukan pada pagi hari. Dilakukan 3 kali ulangan penyerbukan pada bunga. Penyerbukan dengan metode anggrek hitam sebagai tetua jantan dan anggrek mutiara sebagai tetua betina. Hasil penelitian menunjukkan penyerbukan yang berhasil membentuk buah adalah hasil persilangan pada bunga mekar umur 2 hari. Buah dipanen umur 3 bulan akan tetapi buah belum matang sempurna. Perkecambahan biji menggunakan media Vacin \& Went (VW) dan media VW modifikasi. Biji hasil persilangan $C$. pandurata $x$ C. asperata berhasil berkecambah pada media VW modifikasi dengan penambahan auksin $0,1 \mathrm{mg} / \mathrm{l}$ sitokinin $0,1 \mathrm{mg} / \mathrm{l}$ dan berkecambah 9 minggu setelah di tanam.

Kata Kunci: Kultur Jaringan tanaman, hibridisasi, Media VW, fertilitas

\section{ABSTRACT}

Black orchid (Coelogyne pandurata) and Pearl orchid (Coelogyne asperata) are endemic orchid from Kalimantan forest, shape and color suitable as ornamental flower. Many people collected the orchids from the wild for commercial purpose but not much effort on their propagation. To prevent population decreased, propagation and production of new varities via interspesific hybridisation need to be done. An important step required in plant breeding is to obtain cross compatiblity. Cross compatibility of some orchids from Indonesia are not known, including compatibility of Coelogyne pandurata $x$ Coelogyne asperata. Information on compatibility and fertility is very important to produce good quality seed as propagation material. In this research pollination was performed on orchid plants at 
2 until 5 day after flowering and pollination was done in the morning. There are three replicates for each pollination. Pollination was done with $C$. pandurata (black orchid) as male parent and $C$. asperata (pearl orchid) as female parent. The results showed that successful pollination was obtained from pollination at 2 days after flowering. Seed capsule was harvested at 3 months after pollination but not yet perfectly ripe. Seed germination employed in vitro method on Vacin \& Went (VW) and VW with modification media. Seed from $C$. pandurata $x C$. asperata abled to germinate on VW media with addition of $0,1 \mathrm{mg} / \mathrm{l}$ auxin and $0.1 \mathrm{mg} / \mathrm{l}$ cytokinin and germinated 9 weeks after planting.

Keywords: Plant Tissue Culture, Hybridization, Media VW, fertility

\section{PENDAHULUAN}

Keanakeragaman anggrek di Indonesia sangat tinggi, ada sekitar 3.000 jenis berada di Indonesia (Tjitrosoepomo 1993). Beberapa spesies anggrek yang diminati oleh konsumen baik dalam maupun luar negeri adalah jenis Dendrobium (34\%), diikuti oleh Oncidium Golden Shower (26\%), Cattleya (20\%) dan Vanda (17\%) serta anggrek lainnya seperti Coelogyne sp. (3\%) (Litbang Pertanian, 2005).

Coelogyne sp. merupakan anggrek endemik yang hanya ditemukan di beberapa kawasan terbatas di Kalimantan. Contoh Coelogyne adalah Coelogyne pandurata disebut anggrek hitam dan Coelogyne asperata disebut anggrek mutiara. Selain kelangkaannya, anggrek ini memiliki nilai ekonomi yang tinggi karena berpotensi sebagai induk silangan. Anggrek hitam dan anggrek mutiara merupakan anggrek yang statusnya dilindungi (Hartini dan Hary, 2009), sehingga diperlukan upaya untuk menghasilkan jenis maupun varietas baru untuk menambah keanekaragaman jenis anggrek Coelogyne. Penelitian untuk menghasilkan varietas baru dapat dilakukan dengan melakukan persilangan interspesifik yaitu persilangan antar genus.

Salah satu upaya untuk meningkatkan mutu bunga anggrek atau mendapatkan kultivar baru adalah dengan menyilangkan antar tetua yang mempunyai karakter-karakter tertentu. Keunikan karakter kedua anggrek ini adalah anggrek hitam memiliki warna lidah yang hitam pekat dan sepal tepal berwarna hijau muda dan anggrek mutiara memiliki ciri khas berbunga banyak dalam satu tangkai dan harum (Romuald \& Marta, 2015). Oleh karena itu pemuliaan anggrek diupayakan untuk memperluas keragaman genetik pada bentuk dan warna yang unik, disenangi konsumen, frekuensi berbunga tinggi dan tahan terhadap patogen penyebab penyakit serta cekaman lingkungan (Rahmatia dan Pitriana, 2009). Fertilitas berbagai jenis anggrek terutama jenis-jenis anggrek asal Indonesia tidak banyak diketahui. Informasi tentang fertilitas suatu jenis anggrek sangat penting dikuasai untuk dapat memaksimalkan perolehan biji sebagai bahan perbanyakan (Puspitaningtyas dkk., 2006). Coelogyne pandurata dan Coelogyne asperata merupakan jenis anggrek endemik di Kalimantan (Alamendah, 2010), maka dapat diperkirakan bahwa jenis ini tentu memiliki keunikan tersendiri dalam hal perilaku berbunga hingga berbuah. Penelitian ini mengenai studi kompatibilitas dan fertilitas hasil persilangan anggrek khususnya mengenai perkembangan buah dari hasil persilangan, pengamatan embrio biji serta hasil perkecambahan biji hasil persilangan secara in vitro menggunakan media Vacin \& Went (VW).

\section{BAHAN DAN METODE}

\section{Persiapan Penelitian}

Persiapan penelitian meliputi persiapan alat dan bahan serta persiapan induk tanaman anggrek. Anggrek hitam digunakan sebagai tetua jantan dan anggrek mutiara sebagai tetua betina. Pembuatan media kultur biji setelah dilakukan persilangan dan pembuahan. Media kultur yang digunakan adalah media Vacin dan Went (VW) dan media VW dengan penambahan $0,1 \mathrm{mg} / \mathrm{l}$ auksin dan $0,1 \mathrm{mg} / \mathrm{l}$ sitokinin. 


\section{Metode Penelitian}

Penyerbukan dilakukan pagi hari pukul 8 pagi, pada tanaman yang telah mekar penuh pada hari ke 2 dan hari ke 5 setelah mekar. Penyerbukan dilakukan pada 2 tanaman. Dilakukan 3 kali penyerbukan pada masingmasing bunga mekar 2 hari dan bunga mekar 5 hari pada satu tanaman sehingga total ulangan adalah 6 ulangan pada masing-masing bunga mekar 2 dan 5 hari. Polinia di transfer dari anther ke stigma dengan menggunakan tusuk gigi, selanjutnya diberi label nama. Setelah penyerbukan dilakukan maka perkem-bangan pembentukan buah, gugur buah dan kemasakan buah diamati setiap minggu. Uji perkecambahan dilakukan secara secara in vitro pada media Vacin \& Went (VW) (Vacin \& Went, 1949) dan media VW modifikasi auksin : sitokinin dengan konsentrasi masing-masing $0,1 \mathrm{mg} / \mathrm{l}: 0,1 \mathrm{mg} / \mathrm{l}$ untuk melihat kemampuan tumbuh biji yang terbentuk. Pengamatan kultur biji dilakukan seminggu sekali. Buah yang berhasil terbentuk hanya satu buah. Pada uji perkecambahan, kultur biji pada media VW sebanyak 15 ulangan dan kultur biji pada media VW modifikasi 15 ulangan dengan jumlah total 30 ulangan (30 botol). Rancangan percobaan persilangan dan perkecambahan in vitro yang digunakan adalah Rancangan Acak Lengkap (RAL) satu faktor yaitu hari mekar dan jenis media kemudian data dianalisis menggunakan T-Test.

\section{Variabel penelitian}

Variabel yang diamati dari penelitian persilangan yaitu keberhasilan pembentukan buah pada persilangan bunga mekar 2 hari dan bunga mekar 5 hari serta panjang buah. Data deskriptif perkembangan dan pembentukan buah secara morfologi, gugur buah dan tingkat kemasakan buah. Variabel pada penelitian uji perkecambahan adalah persentase keberhasilan biji berkecambah pada media VW dan media VW modifikasi auksin: sitokinin dengan konsentrasi masing-masing $0,1 \mathrm{mg} / \mathrm{l}: 0,1 \mathrm{mg} / \mathrm{l}$.

\section{HASIL DAN PEMBAHASAN}

Hasil persilangan pada umur mekar bunga 2 hari dan 5 hari ditampilkan pada Tabel 1.
Tabel 1. Signifikasi persilangan

\begin{tabular}{llll}
\hline & \multicolumn{3}{c}{ T-Test } \\
& $\mathrm{t}$ & $\mathrm{df}$ & $\mathrm{Sig}$ \\
\hline Hari mekar & 9.950 & 11 & 0.000 \\
\hline
\end{tabular}

Berdasarkan Tabel 1. signifikansi persilangan $(\mathrm{p}<0.05)$ yaitu 0.000 maka hari mekar pada bunga mempengaruhi keberhasilan persilangan.

Buah hasil persilangan dipanen pada umur 3 bulan (9 minggu). Biji pada buah masih berwarna putih. Biasanya warna biji yang matang sempurna berwarna kekuningan dan tidak lengket. Buah dipetik umur tiga bulan karena pada umur empat bulan buah sudah matang mulai pecah (Lestari, 2015). Akan tetapi buah umur tiga bulan tampak kurang matang sempurna dan masih berwarna putih. Persilangan pada bunga umur 5 hari mengalami kerontokan (gagal), sedangkan persilangan pada bunga mekar umur 2 hari berhasil membentuk buah.

Kegagalan persilangan dapat disebabkan oleh beberapa hal seperti reseptivitas stigma dan tingkat kematangan polen. Pada penelitian ini penelitian persilangan pada masa atau umur mekar bunga juga dipengaruhi oleh tingkat reseptivitas dan kematangan polen dimana persilangan yang berhasil pada masa mekar bunga umur 2 hari sedangkan persilangan pada bunga mekar 5 hari tidak berhasil membentuk buah. Menurut Puspitaningtyas dkk. (2006) Phalaenopsis serpentilingua dari hari pertama mekar aromanya sudah tercium, namun masa reseptif stigma paling baik pada hari ke 2-3 setelah mekar, hal ini berkaitan dengan lendir perekat yang lebih lengket bila dibandingkan dengan hari ke-0 pada saat mekar atau hari mekar setelah hari ke-4 karena lendir perekat pada stigma akan mulai berkurang.

\section{Pembentukan buah dan Pengamatan biji}

Masa kuncup hingga mekar memerlukan waktu kisaran 3-4 minggu. Masa mekar bunga beragam mulai dari 6-12 hari. Keberhasilan pembuahan pada persilangan salah satunya dipengaruhi oleh masa resptivitas stigma (Semiarti dkk., 2010). Proses perkembangan buah selanjutnya yang akan menentukan 
pembentukan biji fertil maupun tidak fertil. Ketika bunga sudah mekar sempurna putik sudah siap dibuahi atau stigma sudah receptif (Ronny, 2011).

Umumnya pada bunga anggrek stigma sudah lengket dan siap menerima polen. Persilangan yang dilakukan pada bunga mekar setelah 5 hari mengalami kerontokan. Hal ini kemungkinan disebabkan karena polen sudah pecah dan cairan lengket pada stigma sudah mulai berkurang sehingga masa reseptivitas pada stigma pun mulai berkurang.

Aroma yang dikeluarkan bunga juga merupakan salah satu indikator bahwa bunga telah siap dibuahi. Di alam hal ini digunakan sebagai salah satu strategi untuk menarik perhatian serangga penyerbuknya (Wibisono, 2010). Pada anggrek Coelogyne dari hari pertama mekar aromanya sudah tercium, namun masa receptive stigma paling baik pada hari ke 2-3 setelah mekar (Chen \& Dudley, 2009), hal ini berkaitan dengan lendir perekat yang lebih lengket bila dibandingkan dengan hari ke-0 pada saat mekar.

Hasil penyerbukan pada anggrek hitam dengan anggrek mutiara akan terlihat pada hari ke 3-5 setelah transfer pollen. Bila penyerbukan berhasil, tangkai bunga akan terlihat segar dan bunga mulai layu. Pada penyerbukan yang gagal, tangkai bunga dan bunganya mulai layu berwarna kecoklatan atau pucat dan gugur bersamaan. Bila penyerbukan berhasil maka perkembangan buah akan berlanjut dan diawali dengan pembengkakan (swollen) pada tangkai bunga. Umumnya panjang buah berkembang hingga minggu ke-12 atau ke 15 Minggu Setelah Penyerbukan (MSP). Setelah panjang buah mencapai maksimum, tidak lagi terjadi pertambahan ukuran panjang tetapi dilanjutkan dengan proses perkembangan dan pematangan biji dalam buah. Panjang rata-rata buah hasil penyerbukan berkisar 7-8 cm (Gambar 1). Ukuran buah bukan sebagai indikator bahwa biji tersebut fertil atau tidak fertil. Buah yang berukuran kecil dengan panjang 4-5 cm juga bisa menghasilkan biji-biji yang fertile (Ashgar dkk., 2011).

Pada pengamatan biji secara mikroskopis tampak sebagian besar biji tidak fertil atau tidak mengandung embrio, sedangkan beberapa ada yang fertile atau mengandung embrio. Menurut Semiarti dkk. (2010), tidak semua keberhasilan pada penyerbukan didukung oleh perolehan biji yang selalu fertile. Menurut Puspitaningtyas dkk., (2006), hal ini berkaitan dengan perkembangan buah itu sendiri. Kesehatan tanaman juga berpengaruh pada perkembangan fertilitas biji. Buah yang menghasilkan biji kosong/tak berembrio, belum berarti dikatakan bahwa pembentukan buah gagal akan tetapi bisa disebabkan karena buah dipanen muda. Biji yang sempurna mengandung embrio yang terlihat gelap di bagian tengah biji dan biji kosong tidak mengandung embrio di bagian tengahnya, dilihat dari pengamatan mikroskop.

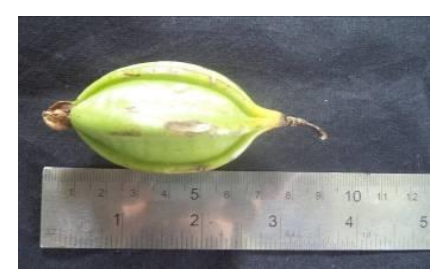

Gambar 1. Buah hasil persilangan C. pandurata X C. asperata

\section{Perkecambahan biji secara in vitro}

Hasil perkecambahan biji pada media VW dan media VW modifikasi secara in vitro telah diuji dengan T-Test ditunjukkan pada Tabel 2.

Tabel 2. Signifikasi pengaruh media pada perkecambahan

\begin{tabular}{llll}
\hline & \multicolumn{3}{c}{ T-Test } \\
& $\mathrm{t}$ & Df & Sig \\
\hline Media & 16.155 & 29 & 0.000 \\
\hline
\end{tabular}

Berdasarkan Tabel 2, signifikansi pengaruh media pada perkecambahan $(\mathrm{p}<0.05)$ yaitu 0.000 maka media pada perkecambahan biji mempengaruhi keberhasilan perkecambahan.

Biji dari buah umur 3 bulan telah dikulturkan pada media Vacin \& Went (VW). Selama 2 minggu pengamatan pada kultur biji belum tampak ada perubahan. Biji tampak masih sama seperti semula ketika baru ditabur 
pada media. Pada buah Coelogyne biasanya matang pada umur buah 4 bulan (Lestari, 2014). Sebagian besar pada umur buah Coelogyne umur lebih dari 4 bulan buah telah matang dan apabila terlalu matang akan mudah pecah (Cheng dkk., 2009). Pada hasil persilangan penelitian ini buah dipanen umur 3 bulan namun buah tampak masih muda kurang matang yang ditandai dengan warna biji yang putih (Gambar 2) dan beberapa sudah berubah warna biji menjadi kekuningan serta biji sedikit lengket. Pemanenan buah muda pada umur kurang dari 4 bulan tidak disarankan karena menghasilkan biji yang steril atau tidak berembrio.

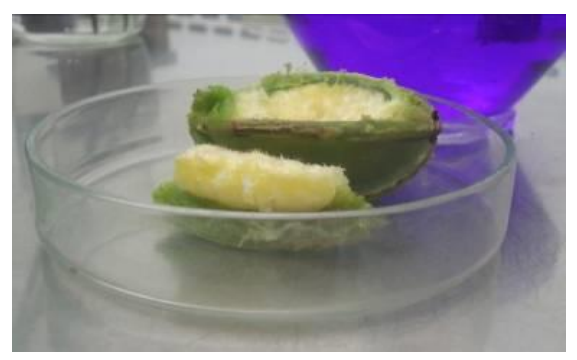

Gambar 2. Biji belum matang

\section{Perkecambahan biji anggrek}

Berdasarkan hasil penelitian perkecambahan pada media VW hingga minggu ke-9 belum menunjukkan respon ataupun pertumbuhan (Gambar 3) sedangkan perkecambahan pada media VW modifikasi yang ditambahkan zat pengatur tumbuh auksin dan sitokinin masing-masing konsentrasi $0,1 \mathrm{mg} / \mathrm{L}$ mulai menunjukkan respon dan mampu berkecambah. Selain merangsang perkecambahan diharapkan ada respon yang terjadi minimal pertumbuhan kalus sehingga dapat dilakukan penelitian selanjutnya.

Perkecambahan pada media VW modifikasi ini telah berumur 9 minggu. Hasil penelitian menunjukkan bahwa biji yang di inisiasi pada media modifikasi dari mulai berkecambah $(33,3 \%)$ pada minggu ke-9 setelah iniasiasi dan umur 16 minggu sudah mulai tumbuh tunas (Gambar 4). Menurut Zulkarnain (2009) tingkat kematangan biji dalam satu buah berbeda karena adanya variasi genetik yang cukup tinggi. Keragaman genetik tersebut juga sangat berpengaruh terhadap proses pematangan biji secara fisiologis.

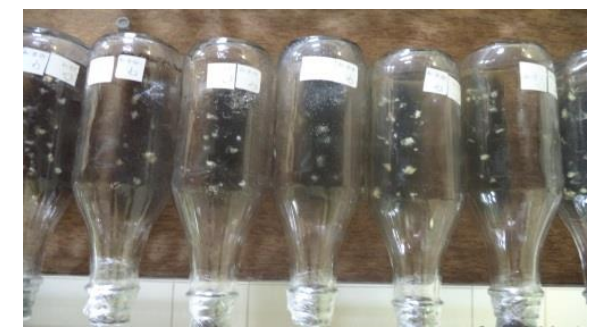

Gambar 3. Perkecambahan biji pada media Vacin \& Went

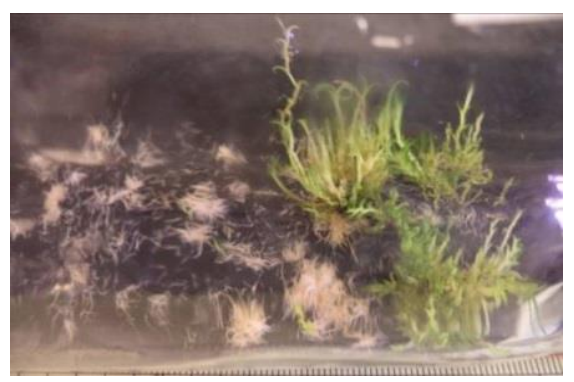

Gambar 4. Tumbuh tunas umur 16 minggu setelah inisiasi biji

Biji yang mampu berkecambah merupa-kan pengaruh penambahan auksin dan sitokinin pada media sehingga mampu merangsang perkecambahan lebih cepat. Menurut Martin dkk. (2006), apabila sitokinin saja ditambahkan pada media kultur kurang berpengaruh terhadap pertumbuhan eksplan, namun jika sitokinin ditambahkan bersama dengan auksin maka selsel akan membelah dan terjadi diferensiasi sel. Pada penelitian ini belum dapat dihitung ratarata biji yang mampu berkecambah karena biji yang berkecambah masih sangat kecil dan baru mulai berkecambah.

\section{KESIMPULAN}

Persilangan $C$. pandurata x $C$. asperata berhasil membentuk buah hasil persilangan hari ke-2 setelah bunga mekar, sedangkan persilangan pada hari ke-5 setelah bunga mekar mengalami kerontokan atau gagal membentuk buah. Buah dipanen pada umur 3 bulan. Biji dalam buah masih lengket dan berwarna putih. 
Biji kurang matang sempurna secara fisiologis. Perkecambahan biji pada media Vacin \& Went (VW) modifikasi hormon auksin:sitokinin dengan konsentrasi $0,1 \mathrm{mg} / \mathrm{l}: 0,1 \mathrm{mg} / \mathrm{l}$ mampu berkecambah dalam waktu 9 minggu.

\section{DAFTAR PUSTAKA}

Alamendah. 2010. Anggrek Hitam Liar Makin Kelam. Available from:

http://alamendah.wordpress.com/2010/01/ 21/anggrek-hitam-liar-makinkelam/.05.03.2013.

Ashgar, S., T. Ahmad, I.A. Hafiz, and Mehwish. 2011. In Vitro propagation of orchid (Dendrobium nobile) var. Emma white. African Journal of Biotechnology 10(16): 3097-3103.

Chen X. and D. Clayton. 2009. Coelogyne Lindl. Flora of China 25: 315-325.

Cheng J., J. Shi, F.Z. Shangguan, A. Dafni, Z.H. Deng, and Y.B. Lou. 2009. The pollination of a self incompatible, foodmimic orchid, Coelogyne fimbriata (Orchidaceae), by female Vespula wasps. Ann. Bot. 104: 565-571.

Litbang Pertanian. 2005. Prospek dan Arah pengembangan agribisnis Anggrek. Available from :

www.litbang.pertanian.go.id/special/kom oditas/files/0104-anggrek.pdf. 04.03.2013

Hartini and H. Wawaningrum. 2009. Coelogyne spp. dan Cymbidium spp. di Cagar alam Gunung sago, Sumatra Barat. Seminar Nasional Konservasi Sumber Daya Hayati:Peran Biosistematika. Purwokerto. Hal. 805-810.

Lestari, N. K. D. 2015. Determining Accurate Harvesting Times of Coelogyne asperata Lindl. Acta Horticulturae 1078: 49-52

Martin K. P., S. K. Pachathundikandi, C.-L Zhang, A. Slater, and J. Madassery. 2006.
RAPD analysis of a variant of banana (Musa sp.) cv Grande Naine, and its propagation via shoot tip culture. In Vitro Cellular and Developmental Biology Plant 42: 188-192.

Puspitaningtyas, D. W., S. Mursidawati., dan S. Wijayanti. 2006. Studi fertilitas anggrek Paraphalaeonopsis serpentilingua (J.J. Sm.) a.D. Hawkes. Biodiversitas 7(3): 237-241.

Rahmatia, D. dan P. Pitriana. 2009. Bunga Anggrek (Seri Flora dan Fauna). Jakarta: Gramedia.

Romuald K., and M. Szkudlarek. 2015. Floral Variability in Selected Species Of The genus Coelogyne Lindl. Orchidaceae. Modern Phyto morphology 8: 27-29.

Ronny Y.G. 2011. Tips Budidaya Anggrek Hitam. Kalimantan Tengah: Badan Litbang Pertanian.

Semiarti, E., A. Indriyanto., E. A.Suyono., R.L. Nurwulan., R. Restiani., Y. Machida., and Chiyoko. 2010. Genetic Transformation of the Indonesian Black Orchid (Coelogyne pandurata Lindley) through Agrobacterium tumefaciens for Micropropagation. Proceeding of NIOC. Nagoya Dome Japan.

Tjitrosoepomo, G. 1993. Taksonomi Tumbuhan (Spermatophyta). Yogyakarta: Gadjah Mada University Press.

Wibisono, S. 2010. Because Orchids is the Queen of the Realm of Plants. Available: http://zoenie-orchids.blogspot.com/2010/ 08/coelogyne-asperata-lindl-1849.html. 11.12.2013.

Vacin E. and F.W. Went 1949. Some $p H$ changes in nutrient solutions. BOT. GAZ. $110: 605-613$

Zulkarnain, H. 2009. Kultur Jaringan Tanaman. Edisi I. Jakarta : Bumi Aksara. 